\title{
Anna KAGANIEC-KAMIEŃSKA
}

Uniwersytet Jagielloński w Krakowie

a.kaganiec-kamienska@uj.edu.pl

\section{RASA CZARNA}

\section{A TOŻSAMOŚĆ KUBAŃSKA}

\section{ABSTRACT Afro-Cubans in the shaping of the Cuban identity}

Many historians point to an important role of race in the shaping of the Cuban identity and culture. Taking as a starting point the view that national identity is dynamic and negotiable, i.e. influenced by the elite's 'national project' and negotiated from below, the article focuses on the role of Afro-Cubans in the formation of Cuban identity until 1959, especially on the period 1898-1940. This article looks at the concept of lo cubano as understood by the Cuban elites as well as the way in which Afro-Cubans actively negotiated their place in the Cuban society.

Key words: Cuba, race, Afro-Cubans, national identity

Słowa kluczowe: Kuba, rasa, Afrokubańczycy, tożsamość narodowa 
Los cubanos son conocidos por ser blancos nacidos en Cuba, descendientes principalmente de españoles.

Rafael Montalvo, Discurso (1884)

En Cuba no hay temor a la guerra de razas. Hombre es más que blanco, más que mulato, más que negro. Cubano es más que blanco, más que mulato, más que negro.

José Martí, Mi Raza (1893)

\section{WPROWADZENIE}

Kuba dzieli z pozostałymi hiszpańskojęzycznymi wyspami karaibskimi cechy wspólne, a wśród nich wspólną historię kolonialną. Równocześnie jednak Karaiby hiszpańskie pod wieloma względami - historycznymi, politycznymi, kulturowymi - stanowią odrębne i różniące się od siebie wyspy. Odmiennie potoczyły się ich losy na drodze ku niepodległości, inaczej rozwijała się ich historia najnowsza. Różnie ukształtowały się także kwestie rasowe.

Peter A. Roberts zauważył, że pojęcie kubańskości powstało w oparciu o miejsce, rasę i język ${ }^{1}$. Rasa, istotnie, zajmuje niezwykle ważne miejsce w długim procesie formowania tożsamości i kultury kubańskiej, na co zwróciło uwagę wielu historyków. Przykładowo Alejandro de la Fuente odnotował, że po zwycięstwie nad Hiszpanią w 1898 r. rasa byta i pozostata kluczowa dla procesu tworzenia narodu². Z kolei Aline Helg stwierdziła, że do lat 20. XX w. (i później) rasa byta bardzo ważnym konstruktem spotecznym wyrażającym hierarchię kubańskiego spoteczeństwa ${ }^{3}$. Rasa nie straciła na znaczeniu również po rewolucji w 1959 r., chociaż pomijana była w oficjalnym dyskursie.

Głównym celem niniejszego artykułu jest ukazanie miejsca rasy czarnej w procesie kształtowania się tożsamości kubańskiej do roku 1959. Rasa czarna rozumiana jest jako konstrukt społeczny oparty przede wszystkim na kolorze skóry.

Szczególny nacisk położono na okres 1898-1940. Przyjęte ramy czasowe mają charakter umowny. Ich początek wyznacza wyzwolenie się Kuby spod kolonialnych rządów Hiszpanii ${ }^{4}$. Następujący po 1898 r. proces kształtowania kultury i tożsamości

P.A. Roberts, The Roots of Caribbean Identity. Language, Race and Ecology, Cambridge 2008, s. 323.

2 A. de la Fuente, A Nation for All. Race, Inequality, and Politics in Twentieth Century Cuba, Chapel Hill 2001, s. 23, Envisioning Cuba Ser.

3 A. Helg, Our Rightful Share. The Afro-Cuban Struggle for Equality, 1886-1912, Chapel Hill-London 1995, s. 12-13.

4 Droga Kuby do niepodległości wiodła przez kilka powstań (wojna dziesięcioletnia, 1868-1878; mała wojna - La Guerra Chiquita, 1879-1880; wojna o niepodległość, 1895-1898, zakończona amerykańską interwencją) oraz amerykańską okupację (1898-1902). Obowiązująca do 1934 r. poprawka Platta z 1902 r. zapewniała USA praktyczną możliwość interwencji w sprawy Kuby w określonych wypadkach. 
kubańskiej nie zawsze przebiegał w oderwaniu od politycznych i ideologicznych wpływów zagranicznych, głównie Stanów Zjednoczonych. De la Fuente zauważa w tym kontekście, że na Kubie niektóre z najbardziej znaczących czynników „wewnętrznych” (domestic) miaty $w$ rzeczywistości charakter zagraniczny ${ }^{5}$. Rok 1940 wyznaczający koniec wskazanych ram czasowych jest datą publikacji klasycznej dziś książki Contrapunteo cubano del tabaco y el azucar autorstwa wybitnego kubańskiego antropologa Fernando Ortiza. Książka ta jest kubańskim manifestem ideologii „demokracji rasowej”, która przedefiniowała dotychczasowe spojrzenie na tożsamości narodowe i kulturowe. Koncepcja ta zaakceptowała i zrehabilitowała wkład grup nieeuropejskich w rozwój tożsamości i kultury społeczeństw regionu. Do pierwszej dekady XX w. w regionie Ameryki Łacińskiej dominowała bowiem koncepcja ulepszania społeczeństwa, co próbowano osiągnąć m.in. poprzez „wybielającą” społeczeństwo europejską imigrację oraz eliminację lub inkorporację Indian. Intelektualiści latynoamerykańscy zrewidowali jednak swoje poglądy na temat rasy wraz ze zmianą sposobu postrzegania Stanów Zjednoczonych i Europy, jak dotąd uznawanych za wzory do naśladowania ${ }^{7}$. W Peru i Meksyku, a więc w krajach o dużej populacji Indian, wyłonił się wówczas szeroki nurt znany jako indygenizm (indigenismo), który ostatecznie miał jednak na celu asymilację Indian poprzez ich edukację i integrację ${ }^{8}$. $Z$ kolei przewartościowanie metysażu znalazło swoje odzwierciedlenie w koncepcji „rasy kosmicznej” Meksykanina José Vasconcelosa (1925) czy wspomnianej „demokracji rasowej” Brazylijczyka Gilberto Freyre'a $(1933,1936)^{9}$.

Publikacja Contrapunteo cubano zasługuje na szczególną uwagę, ponieważ w książce tej Fernando Ortiz po raz pierwszy użył terminu „transkulturacja” (transculturación) w odniesieniu do interakcji i „transmutacji” kultur na Kubie - kultur rodzimych, kultury hiszpańskich kolonizatorów, kultur niewolników afrykańskich oraz imigrantów przybywających w różnym okresie i natężeniu z Europy czy Azji. Autor zaproponował, aby „transkulturacja” w dyskursie socjologicznym zastąpiła amerykańską

A. de la Fuente, A Nation for All..., s. 10. De la Fuente zwraca uwagę na to, że szczególnie w okresie I republiki (1902-1933) Amerykanie kontrolowali produkcję cukru i stanowili ważną siłę polityczną.

6 G.R. Andrews, Afro-Latin America, 1800-2000, Oxford-New York 2004, s. 166.

7 H.J. Wiarda, The Soul of Latin America. The Cultural and Political Tradition, New Haven-London 2001, s. 198-203; J. Larrain, Identity and Modernity in Latin America, Malden, Mass. 2000, s. 81-86. Nancy P. Appelbaum, Anne S. Macpherson i Karin Alejandra Rosemblatt wskazują na cztery okresy w rozwoju dyskursu elit na temat rasy: (1) początek XIX w. (grupy kolorowe wyłączone poza nawias); (2) koniec XIX w. (duże znaczenie „białej cywilizacji” i wybielanie społeczeństw regionu); (3) rewizja dotychczasowego stanowiska (uznanie metysażu); (4) po II wojnie światowej (rewizja „demokracji rasowej”). Szerzej zob. N.P. Appelbaum, A.S. Macpherson, K.A. Rosemblatt, Introduction. Racial Nations, [w:] Race and Nation in Modern Latin America, red. też, New York 2003, s. 3-9. Szerzej na temat rasy w Ameryce Łacińskiej zob. P. Wade, Race and Ethnicity in Latin America, New York 1997.

8 Szerzej zob. A. Posern-Zieliński, Między indygenizmem a indianizmem. Andyjscy Indianie na drodze do etnorozwoju, Poznań 2005, Etnologia i Antropologia Kulturowa - Uniwersytet im. Adama Mickiewicza w Poznaniu, nr 22.

9 G. Freyre, Casa Grande e Senzala, 1933 (pol. Panowie i niewolnicy); Sobrados e Mucambos, 1936. 
koncepcję „akulturacji”, ponieważ, jego zdaniem, termin ten lepiej oddawał procesy, jakie prowadziły do wytworzenia się kultury kubańskiej, a w szerszej perspektywie kultur amerykańskich w ogóle ${ }^{10}$. Ortiz zajmował się jednak miejscem i rolą czarnych niewolników na Kubie również we wcześniejszych pracach. W tym kontekście warto przywołać Hampa afro-cubana. Los negros esclavos z 1916 r., w której analizował historię i realia niewolnictwa na wyspie, pochodzenie i charakterystykę niewolników, jak również ich zwyczaje i tradycje ${ }^{11}$. Data publikacji Contrapunteo cubano jest pewnym symbolicznym wyrazem zmian zachodzących na Kubie, bowiem, używając terminu Robina D. Moora, „nacjonalizacja” korzeni afrykańskich następowała tutaj stopniowo w latach poprzedzających wydanie tej książki. Słowem, do lat 40. XX w. z rasowo „białej” Kuba stała się „metyska”.

Punktem wyjścia rozważań nad miejscem rasy w formowaniu tożsamości kubańskiej jest założenie, że tożsamość zbiorową (w tym przednarodową i narodową) należy postrzegać jako kategorię dynamiczną (konstruowaną i rekonstruowaną). W jej formowaniu uczestniczą pozostające we wzajemnej relacji zarówno czynniki i procesy kierowane odgórnie, jak i oddziałujące oddolnie ${ }^{12}$. Z jednej strony mamy zatem do czynienia z pewną wizją, swoistym ideologicznym projektem narodu i tożsamości narodowej według elit rządzących. Projekt ten budowany jest na bazie pewnych wybranych elementów i często w opozycji do innej zbiorowości. Z drugiej strony wyzwanie takiej „odgórnej” wizji rzucają jednostki i grupy, które reagując na zmieniające się konteksty społeczne, kulturowe i polityczne, na swój sposób ją „negocjują”.

Artykuł stanowi próbę odpowiedzi na pytanie, jaką rolę w wizji „kubańskości” (lo cubano $)^{13}$ propagowanej przez władzę polityczną odgrywała grupa o afrykańskich korzeniach oraz w jaki sposób wizja ta była oddolnie „negocjowana” ${ }^{14}$.

10 F. Ortiz, Contrapunteo cubano del tabaco y el azucar, Caracas 1978, s. 93. Na marginesie warto wspomnieć, że zainteresowanie procesami akulturacji grupy o afrykańskich korzeniach przejawiano wówczas również w Stanach Zjednoczonych. W 1941 r. Melville J. Herskovits, uczeń Franza Boasa, opublikował książkę The Myth of the Negro Past. Herskovits uważał, że możliwa była asymilacja czarnych do społeczeństwa USA przy równoczesnym zachowaniu przez nich afrykańskiego dziedzictwa. Ponadto, jego zdaniem, biała i czarna kultura miały na siebie wpływ (czarni znajdowali się pod wpływem kultury białych Amerykanów, a ich kultura miała wpływ na kulturę grupy białej). M.J. Herskovits, The Myth of the Negro Past, New York-London 1941, [online] https://archive.org/details/mythofthenegropa033515mbp, 26 III 2017; J. Gershenhorn, Melville J. Herskovits and the Racial Politics of Knowledge, Lincoln-London 2004, s. 93-94. W samych Stanach Zjednoczonych kwestia rasy pozostawała bardzo ważnym tematem. Zob. np. Race and Ethnicity in America. A Concise History, red. R.H. Bayor, New York 2003.

11 F. Ortiz, Hampa afro-cubana. Los negros esclavos; estudio sociológico y de derecho público, Havana 1916, [online] https://archive.org/details/hampaafrocubanal00ortiuoft, 25 III 2017.

12 Por. „tożsamość konstruowana” oraz „model opinii publicznej” w: Z. Bokszański, Tożsamości zbiorowe, Warszawa 2005, s. 122-135. Por. też rozumienie tożsamości u socjologa Jorge Larraina. J. Larrain, Identity and Modernity in Latin America, s. 34-38.

13 W niniejszym artykule używany jest termin lo cubano, jakkolwiek w literaturze przedmiotu w różnych kontekstach pojawiają się także cubanidad oraz cubanía.

14 Por. na temat kształtowania się stosunków rasowych na Kubie: A.P. Maingot, Race, Color, and Class in the Caribbean, [w:] Americas. New Interpretative Essays, red. A. Stepan, New York 1992, s. 224. 
Ważnymi pojęciami w tym kontekście są metysaż (mestizaje, zjawisko mieszania się ras i kultur, w przypadku metysażu kulturowego) oraz kreolizm (criollismo, nadający szczególne znaczenie miejscu urodzenia). Zagadnienie metysażu stanowi w Ameryce Łacińskiej jeden z kluczowych tematów, chętnie i szeroko podejmowanych przez latynoamerykańskich intelektualistów. W XIX w. mestizaje pojawiał się jako metafora powiązana z poszukiwaniem amerykańskości (lo americano) - w opozycji do tego, co europejskie i anglo-amerykańskie. Z kolei od lat 20. do 60. XX w., a więc w okresie konsolidacji narodowej i modernizacji, koncepcja metysażu uwypuklała tożsamość kulturową lo cubano, lo mexicano etc. ${ }^{15}$

Pojęcie criollo (Kreol ${ }^{16}$ oznaczało w szerszym znaczeniu wszystkich urodzonych na Kubie, bez względu na rasę, zaś w węższym znaczeniu odnosiło się do urodzonych na wyspie dzieci Europejczyków i dzieci Afrykańczyków ${ }^{17}$. Tak jak miejsce urodzenia odróżniało białych Kreolów od penisulares (pochodzących z Hiszpanii), tak dla czarnoskórych bycie Kreolem odróżniało ich od bozales (niewolników przywożonych na wyspę z Afryki). W XIX w. criollismo jako ideologia symbolizowało na hiszpańskich Karaibach niepodległość, niezależność od Hiszpanii. Kreolizm, jak zauważa Roberts, powstał w oparciu o kilka elementów, m.in.: element rodzimy (w odróżnieniu od obcego - zarówno penisular, jak i bozal) i element rasy mulackiej. I chociaż miał - przynajmniej w zapewnieniach - odnosić się do wszystkich ras, w rzeczywistości, jak pisze Roberts, byt raczej biatym ruchem intelektualnym niz spontaniczna ekspresja narodowej czy regionalnej powszechnej tożsamości politycznej ${ }^{18}$.

\section{KUBA PRZED 1898 R. KONTEKST HISTORYCZNY. NARODZINY LO CUBANO}

Proces formowania kubańskiej tożsamości narodowej przed 1959 r. można analizować w trzech okresach: kolonialnym (do 1898 r.), dominacji wizji „białej” oraz Kuby „metyskiej”.

W połowie XVIII w. Kuba nie była ani szczególnie gęsto zaludniona, ani zagospodarowana. Mieszkało tutaj wówczas mniej niż 200 tys. osób, w tym 50 tys. niewolników ${ }^{19}$. Do tego czasu wyspa przyjęła zatem stosunkowo niewielką liczbę niewolników ${ }^{20}$. Do zmiany tego stanu rzeczy przyczyniła się trwająca niemal rok okupacja

15 L. Martinez-Echazabal, Mestizaje and the Discourse of National/Cultural Identity in Latin America 1845-1959, „Latin American Perspectives” 1998, Vol. 25, nr 3, s. 21.

16 Na temat samego pojęcia i ewolucji jego znaczenia w Ameryce Hiszpańskiej zob. np. P.A. Roberts, The Roots of Caribbean Identity..., passim.

17 Tamże, s. 318.

18 Tamże, s. 338-339.

19 T. Łepkowski, Archipelagu dzieje nietatwe. Obrazy z przesztości Antyli XV-XX w., Warszawa 1964, s. 213, Biblioteka Wiedzy Historycznej. Historia Powszechna; Dzieje Ameryki Łacińskiej, t. 1, red. T. Łepkowski, Warszawa 1977, s. 59; G.R. Andrews, Afro-Latin America..., s. 17-19.

20 Szerzej na temat składu grupy hiszpańskich kolonizatorów i późniejszych imigrantów zob. J. Guanche, 
wyspy przez Brytyjczyków, która równocześnie uświadomiła Hiszpanom drzemiący w niej potencjał (zarówno jako portu, jak i terenów rolniczych). Opuszczając Hawanę w 1763 r., Brytyjczycy podpisali z przejmującymi władzę Hiszpanami kontrakt na przywiezienie na wyspę 10 tys. niewolników. W kolejnych latach ich liczba znacząco wzrosła $^{21}$. Po całkowitym zniesieniu przez Koronę ograniczeń na handel niewolnikami do swoich kolonii w 1789 r. - odnotowano olbrzymi import sily roboczej z Afryki. O ile w latach 1764-1790 na wyspę przywożono około 2 tys. niewolników rocznie, o tyle w okresie 1790-1810 liczba ta wzrosła do ponad 7 tys. ${ }^{22}$ Było to związane z rozwojem gospodarki plantacyjnej na wyspie, do czego przyczyniły się m.in. przemiany zachodzące na niehiszpańskich Karaibach i zachwianie ich pozycji jako wiodących producentów cukru. Po rewolucji na Haiti (1791-1804) Kuba de facto przejęła rolę największego wytwórcy cukru ${ }^{23}$. W 1817 r., pod naciskiem Wielkiej Brytanii, która zniosła handel niewolnikami w roku 1807, Hiszpania zobowiązała się zlikwidować ten proceder do $1820 \mathrm{r}$. Jednak trwał on nielegalnie w zasadzie do lat 70. XIX w. ${ }^{24} \mathrm{Jak}$ podaje Ada Ferrer, w latach 1816-1867 przywieziono tam niemal 600 tys. osób, czyli więcej niż kiedykolwiek sprowadzono do USA (523 tys. ${ }^{25}$. W czasie walk niepodległościowych na kontynencie południowo-i środkowoamerykańskim Kuba pozostała lojalna względem Hiszpanii i najdłużej, bo do 1886 r., utrzymała system niewolniczy. Tymczasem w koloniach brytyjskich abolicja weszła w życie 1 sierpnia 1834 r. (przy czym dorosłych niewolników objęto przejściowym okresem półwolności - ostatecznie uzyskali oni wolność cztery lata później), zaś niewolnictwo w koloniach francuskich zniesiono w $1848 \mathrm{r}^{26}$

Czarni niewolnicy znacząco zmienili rasową strukturę Kuby. Około 1800 r. osoby o korzeniach afrykańskich stanowily $54 \%$ populacji liczącej wówczas 600 tys. osób (35\% niewolnicy i $19 \%$ wolni $)^{27}$. Co prawda Cedula z 1815 r. zezwoliła na osadnictwo osób spoza półwyspu hiszpańskiego, jednak nie wywarli oni wówczas zasadniczego wpływu na rasową strukturę społeczeństwa. Warto podkreślić stosunkowo

Componentes étnicos de la nación cubana, Warszawa 2004, s. 23-32, Dokumenty Robocze - Uniwersytet Warszawski. Centrum Studiów Latynoamerykańskich, 40.

21 T. Łepkowski, Archipelagu dzieje nietatwe..., s. 213-214.

22 G.R. Andrews, Afro-Latin America..., s. 17-19.

23 Przemysł cukrowy był największym (ok. 43\%), choć nie jedynym, sektorem zatrudnienia niewolników. R.L. López Valdés, Pardos y Morenos esclavos y libres en Cuba y sus instituciones en el Caribe Hispánico, San Juan 2007, s. 45-56, 63-69, 84, Biblioteca del Centro.

T. Łepkowski, Archipelagu dzieje nietatwe..., s. 214; G.R. Andrews, Afro-Latin America..., s. 57.

25 A. Ferrer, Insurgent Cuba. Race, Nation, and Revolution, 1868-1898, Jamaica 1999, s. 2. Por. G.R. Andrews, Afro-Latin America..., s. 69. Szerzej na temat pochodzenia etnicznego niewolników na Kubie zob. np. J. Guanche, Identificación de los componentes étnicos en Cuba. Contribución a su studio en los siglos XX y XXI, „Revista del CESLA” 2005, nr 7, s. 237-251; tenże, Componentes étnicos..., s. 33-51; na temat obecności niewolników w Ameryce Łacińskiej zob. też B. Lisocka-Jaegermann, Czarne Afryki, [w:] Dzieje kultury latynoamerykańskiej, red. M.F. Gawrycki, Warszawa 2009.

26 T. Łepkowski, Archipelagu dzieje nietatwe..., s. 193, 201-204.

27 Zob. G.R. Andrews, Afro-Latin America..., s. 41 (Tabela 1.1). 
wysoki odsetek wyzwoleńców (w Portoryko był on nawet większy niż na Kubie i około 1800 r. wynosił aż $40 \%$ populacji wyspy). Tłumaczy się to ogólnie większym wymieszaniem rasowym populacji oraz mniejszym znaczeniem niewolników w okresie przedplantacyjnym. I tak, w 1786 r. na brytyjskim Barbadosie wyzwoleńcy stanowili jedynie $1 \%$ całej populacji, a niewolnicy aż $78,5 \%$. Na Jamajce w 1775 r. proporcje te wynosiły odpowiednio 2\% i 89\%, na francuskiej Martynice - 5,4\% i 86\%, a na Saint-Domingue (które wkrótce potem wywalczyło niepodległość jako Haiti) - 5\% i $88 \%{ }^{28}$. Na tle innych gospodarek plantacyjnych Karaiby hiszpańskie wypadały zatem pod tym względem korzystnie ${ }^{29}$.

Paradoksalnie społeczeństwo oparte na gospodarce plantacyjnej i pracy niewolniczej stworzyło pewne możliwości awansu społecznego dla wolnych czarnych i Mulatów. Niewolnicy mogli uzyskać wolność z rąk właściciela (manumisión) - np. na mocy testamentu. Panowie uwalniali również swoje nieślubne dzieci. Niewolnikom przysługiwało ponadto prawo do samodzielnego wykupienia się z niewoli. Jak wynika z danych Moreno Fraginalisa, od XVII w. do początku XVIII w. w ponad $80 \%$ przypadków niewolnicy uzyskali wolność poprzez samodzielne wykupienie (coartación). Już w XVIII w. istniała zatem grupa wolnych czarnych i mulackich rzemieślników (malarze, rzeźbiarze, muzycy etc.). Jak podaje Rafael López Valdés, w 1862 r. 21\% populacji Hawany stanowili wolni czarnoskórzy (morenos) i Mulaci (pardos). Jeśli natomiast przyjrzeć się proporcjom w obrębie grupy, można stwierdzić, że aż 60\% czarnych i Mulatów w Hawanie i Santiago de Cuba cieszyło się wolnością ${ }^{30}$. Wyzwoleńcy kolorowi musieli jednak stawić czoła różnym ograniczeniom.

\section{RAZADE COLOR}

Jak zauważa Aline Helg, na Kubie wykształcił się unikalny system rasowy, lokujący się pomiędzy wielostopniowym systemem funkcjonującym w innych rejonach Ameryki hiszpańskiej a dychotomicznym systemem istniejącym w USA. Helg argumentuje, że o specyfice tej świadczy powstanie kategorii rasowej raza de color (lub clase de color), która nie rozróżniała Mulatów i czarnych. W tym aspekcie system kubański podobny był do amerykańskiego. Różniło go jednak to, że na Kubie czarnych i Mulatów oddzielały od białych „widoczne” korzenie afrykańskie, nie zaś - jak w wypadku Stanów Zjednoczonych - zasada jednej kropli krwi (one drop rule). Koncepcja raza de color prawdopodobnie wyłoniła się na skutek spisku La Escalera (1844), którego stłumienie prowadziło ostatecznie do ograniczenia praw wolnych ludzi kolorowych, przez co ich

28 G. Heuman, The Social Structure of the Slave Societies in the Caribbean, [w:] General History of the Caribbean, t. 3, red. F.W. Knight, London-Basingstoke 1997, s. 144; por. Dzieje Ameryki Eacińskiej, t. 1, s. 59.

29 Por. dane dla Ameryki kontynentalnej: G.R. Andrews, Afro-Latin America..., s. 41 (Tabela 1.1), 44-47.

30 R.L. López Valdés, Pardos y Morenos esclavos..., s. 58-59, 82. 
pozycja stała się podobna do czarnych ${ }^{31}$. Po 1844 r. sytuacja czarnych wyzwoleńców znacznie się pogorszyła (konfiskaty majątków, zdziesiątkowanie), jednak czarna klasa średnia i klasa średnia wyższa zdołały się odbudować. Mimo niskiego statusu społecznego czarni wyzwoleńcy radzili sobie dobrze pod względem awansu ekonomicznego ${ }^{32}$, co budziło opór białych dążących do utrzymania ich w pozycji podrzędnej. Nie chcieli oni dopuścić, by $w$ podrzędnej i zdegradowanej klasie obudziła się idea równości33.

\section{MIĘDZYRASOWE ZWIĄZKI MAŁŻEŃSKIE}

Obawa przed afrykanizacją wyspy prowadziła do poczynienia jeszcze innych dotkliwych kroków. Verena Martinez-Alier w swojej książce Marriage, Class and Colour in Nineteenth-Century Cuba, w której szczegółowo analizuje i opisuje kolejne losy i zawirowania wokół praw do zawierania międzyrasowych związków małżeńskich, zauważyła, że od 1864 r. do połowy lat 70. XIX w. nie wydano ani jednej oficjalnej zgody na zawarcie związku mieszanego rasowo ${ }^{34}$. Tłumaczono to zawieszeniem w tym względzie uprawnień odpowiednich organów władzy na terytoriach zamorskich do czasu wyjaśnienia niejasnych kwestii. Jednak nierzadko sami kolorowi mieli obiekcje co do wybranek i wybranków serca swoich dzieci ${ }^{35}$. Głównym celem był postęp - zarówno wybielenie rasowe (poślubienie jaśniejszego), jak i status prawny wybranka (poprzez "oddalenie się" od niewolnictwa). Wpływ miały też jednak reputacja i walory ekonomiczne (np. posiadanie domów, niewolników).

Można zatem powiedzieć, że ludność o korzeniach afrykańskich przyjęła i zinternalizowała dyskryminującą ideologię białych. Jednym słowem, uwierzyła, że sposobem na poprawienie swojej pozycji było rozjaśnienie koloru skóry (adelantar la raza).

\section{LO CUBANO}

Jak zauważa Roberts, koncepcja kubańskości (lo cubano), odmiennej od hiszpańskości (zmiana z criollo na cubano), wyodrębniła się na początku XIX w. Narodziła się

31 A. Helg, Our Rightful Share..., s. 3-4, 15.

32 Zob. np. V. Martinez-Alier, Class and Colour in Nineteenth-Century Cuba. A Study of Racial Attitudes and Sexual Values in a Slave Society, Ann Arbor 1989, s. 98-99.

33 Cyt. za: G.R. Andrews, Afro-Latin America..., s. 109.

34 V. Martinez-Alier, Class and Colour.., s. 32, 39. Ostatecznie w 1881 r. wydano dekret zezwalający na związki międzyrasowe. Tamże, s. 40 .

35 Martinez-Alier podaje, że wśród kolorowych istniało co najmniej dziewięć różnych typów ludzi wolnych. Szerzej zob. V. Martinez-Alier, Class and Colour..., s. 91-98. Autorka pokazuje, jak blisko powiązane były ze sobą kolor (legal colour and real colour - mogące się różnić) oraz klasa. Chińczycy, przykładowo, mimo swojego „białego” koloru (legalnie) mogli zostać odrzuceni jako kandydaci na męża przez matki ciemnoskórych kobiet. Świadczy to, że biel nie była jedynym kryterium wyboru - w tych przypadkach chodziło raczej o wykonywaną pracę i związany z nią status ekonomiczny. Zob. tamże, s. 79. 
zatem idea Kubańczyka jako - używając słów intelektualisty José Antonio Saco - potomka Hiszpanów, urodzonego i wychowanego na Kubie, katolika mówiacego po hiszpańsku ${ }^{36}$. Wśród przekonań przywiezionych na ten teren przez kolonizatorów te dotyczące różnic rasowych zajmowały kluczową pozycję (idea „czystości rasowej”) ${ }^{37}$. Co więcej, według oficjalnego dyskursu kolonialnego Kubańczycy nie mogli być narodem ze względu na dużą grupę czarnych oraz społeczne i ekonomiczne znaczenie niewolnictwa ${ }^{38}$. Kiedy zatem w połowie XIX w. Saco popierał mieszanie się ras (związki białych mężczyzn z kolorowymi kobietami, ale nie odwrotnie), nie wspierał on idei color Cubano, color mestizo/Cuba mestiza czy "transkulturacji”, jak to zrobią później Jose Martî́ ${ }^{39}$ (1891, 1893), Nicolas Guillén (1930) czy Fernando Ortiz (1940). W tym okresie liczebnie dominowała grupa czarnoskóra, a Saco wpisywał się w dominujący wówczas dyskurs (racialized discourse) uznający wyższość rasową i kulturową świata zachodniego i promujący „ulepszenie” populacji poprzez jej wybielenie $^{40}$. O tym, jak wyraźne były granice między grupami, świadczy m.in. to, że również biali podlegali swoistej „hierarchizacji”. Według hierarchii, jaką w 1840 r. przedstawił David Turnbull, brytyjski konsul na wyspie i działacz na rzecz zniesienia niewolnictwa, większość białych Kreoli plasowała się poniżej urodzonych poza Kubą mieszkańców wyspy, co znacząco podkreśla istniejącą wówczas opozycję między penisular a criollo ${ }^{41}$.

W odróżnieniu od Indianina siboney ${ }^{42}$ oraz rolnika guajiro ${ }^{43}$ postać czarnej osoby (Negro) kojarzyła się negatywnie i nie była uważana za cubano, choć z racji urodzenia w Nowym Świecie była przecież criollo ${ }^{44}$. Czarnoskórzy postrzegani byli jako zagrożenie (również pod względem językowym) ${ }^{45}$. Strach przed tym, żeby Kuba nie podzieliła losu Haiti, potęgowały dodatkowo oskarżenia o kolejne spiski (m.in. 1812, 1825, 1835 i 1844$)^{46}$. Obawy przed powtórzeniem się scenariusza haitańskiego były obecne także zarówno w czasie walk rozpoczętych w 1868 r., jak i podczas La Guerra Chiquita (1879-1880). Niektórzy Kubańczycy rozważali aneksję wyspy przez USA jako

36 P.A. Roberts, The Roots of Caribbean Identity..., s. 321-323.

37 A.P. Maingot, Race, Color, and Class..., s. 224.

38 A. Ferrer, Insurgent Cuba..., s. 8.

39 „Mi raza” (1891); „Nuestra America” (1893). L. Martinez-Echazabal, Mestizaje, s. 30.

40 L. Martinez-Echazabal, Mestizaje, s. 28-30.

${ }^{41}$ Zob. P.A. Roberts, The Roots of Caribbean Identity..., s. 322.

42 Rodzimy mieszkaniec Karaibów, celowo wydobyty w XIX w. z mroków historii i zrekonstruowany dla celów literackich i politycznych. Roberts określa ciboneyismo jako niezbyt dobrą, ale popularną w XIX w. literaturę. P.A. Roberts, The Roots of Caribbean Identity..., s. 325-330, 340.

43 Na Kubie wieśniak, rolnik; syn campesino.

44 Szerzej na temat siboney oraz guajiro zob. P.A. Roberts, The Roots of Caribbean Identity..., s. 325-339.

45 Szerzej zob. tamże, passim.

46 G.R. Andrews, Afro-Latin America..., s. 107. Na temat innych kroków poczynionych przez Koronę na Kubie w celu ograniczenia kontaktu wolnych czarnych z niewolnikami oraz z wolnymi czarnymi z innych krajów zob. tamże, s. 108. 
najkorzystniejszą opcję. Wspominał o tym w swoich pismach z 1869 r. Manuel Céspedes, który zainicjował powstanie z 1868 r., darowując swoim niewolnikom wolność (on sam zresztą był wcześniej związany z ruchem ,aneksjonistycznym”) ${ }^{47}$. Strach przed czarnoskórymi okazał się zatem większy niż obawa przed USA. Z kolei w czasie La Guerra Chiquita, jak podaje Ferrer, oficerowie kolonialni manipulowali informacjami, by pokazać, że był to „ruch czarnych”. Przykładowo, listy pojmanych powstańców zawierały tylko nazwiska osób czarnoskórych ${ }^{48}$.

\section{KUBAŃCZYK WEDŁUG ELIT POLITYCZNYCH. PIERWSZE DEKADY}

Po 1898 r. Kuba znalazła się pod okupacją amerykańską, w czasie której faworyzowano białych, a Afrokubańczyków marginalizowano i dyskryminowano ${ }^{49}$. W 1900 r. władze amerykańskie ograniczyły czynne prawo wyborcze do osób piśmiennych, posiadających określony majątek lub walczących w Armii Wyzwolenia, co de facto odbierało prawo głosu pewnej grupie osób o afrykańskich korzeniach ${ }^{50}$. W tym czasie nie wprowadzono także żadnych zmian w obowiązującym jak dotąd hiszpańskim kodeksie karnym (faworyzującym białych), a stanowiska publiczne powierzono białym, konserwatywnym Kubańczykom ${ }^{51}$. Taka wizja narodu wykluczającego pewne sektory społeczeństwa odpowiadała również niektórym Kubańczykom.

Co ciekawe, spis powszechny przeprowadzony na Kubie w 1899 r. pod okupacją amerykańską (a więc przez Amerykanów i „dla Amerykanów”) ${ }^{52}$ ukazał Kubę jako stosunkowo białą w porównaniu z wcześniejszymi danymi. Jedną trzecią mieszkańców sklasyfikowano jako Mulatów i Murzynów. Interesujące jest to, że kategoria „biały" została podzielona na native-born whites oraz foreign-born whites (np. Hiszpanie). Jak zaznacza Mara Loveman, prawdopodobnie odzwierciedlało to sceptycyzm amerykańskich urzędników co do „bieli” skóry osób „białych” urodzonych na Kubie ${ }^{53}$. Ilustruje to fakt, że Amerykanie zaliczyli do ludności niebiałej Chińczyków, klasyfikowanych wcześniej przez Hiszpanów jako „białych”. Ponadto podczas gdy na Kubie wagę przykładano do koloru skóry danej osoby, w USA rasę czarną określano na podstawie jej korzeni (podejście biologiczne, genealogiczne). Przykładowo, w $1924 \mathrm{r}$. w amerykańskim stanie Wirginia przyjęto Act to Preserve Racial Integrity, zgodnie

\footnotetext{
A. Ferrer, Insurgent Cuba..., s. 53-54, 197; T. Łepkowski, Archipelagu dzieje nietatwe..., s. 247.

A. Ferrer, Insurgent Cuba..., s. 8.

Szerzej zob. np. A. de la Fuente, A Nation for All..., s. 39-45.

Szerzej zob. tamże, s. 56-58.

51 Szerzej zob. A. Helg, Our Rightful Share..., s. 91-101.

52 Spis miał określić liczbę i rodzaj potencjalnych wyborców (według nowego prawa wyborczego). M. Loveman, National Colors. Racial Classification and the State in Latin America, New York 2014, s. 143.

53 Tamże, s. 148, 185. Zob. np. Report on the Census of Cuba 1899, Table VI, University Libraries Digital Collections, np. s. 129, 194, [online] http://library.sc.edu/digital/collections/cubancensus.html, 20 XII 2015.
} 
z którym osoby o jakiejkolwiek domieszce krwi murzyńskiej uznawane były za czarne (zasada ,jednej kropli krwi”) ${ }^{54}$.

\section{MIT RÓWNOŚCI RASOWEJ}

W czasie 30 lat wspólnej walki wszystkich grup rasowych o niepodległość Kuby ukształtowała się „nacjonalistyczna ideologia rewolucyjna”, wedle której wszyscy Kubańczycy mieli być równymi członkami narodu 55 . Jednak, jak pokazuje Alejandro de la Fuente, ideologia nacjonalistyczna miała różne interpretacje, a co za tym idzie różne grupy mogły powoływać się na ten sam dyskurs José Martíego ${ }^{56} \mathrm{i} w$ radykalnie odmienny sposób wyjaśniać związek między narodem a rasą ${ }^{57}$. Sam José Martí idealistycznie podkreślał jedność oraz równość czarnych i białych względem siebie. Koncepcja ta zderzyła się z dotychczasowymi argumentami hiszpańskich władz kolonialnych, według których Kubańczycy nie mogli być narodem m.in. ze względu na liczbę czarnych niewolników ${ }^{58}$. W 1894 r. Martí wyjaśniał także, że czarny Kubańczyk nie dąży do wolności [...] sprawiedliwości politycznej i niepodlegtości jako cztowiek czarnoskóry, ale jako Kubań$c z y k^{59}$. Inne ważne słowa wypowiedział Antonio Maceo, czarnoskóry generał i powstaniec, stwierdzając, że nie ma biatych ani czarnych, ale sa Kubańczycy. Słowa Martíego, iż niewolnicy zostali uwolnieni przez swoich właścicieli podczas wojny o niepodległość, były później paradoksalnie wykorzystywane na potwierdzenie tezy, że problem rasowy na Kubie został rozwiązany w czasie walk o niepodległość.

Konserwatywna interpretacja ideologii nacjonalistycznej wyznawana przez główne partie polityczne głosiła braterstwo ras. Według tej interpretacji równość ras została już osiągnięta, jednak jedynie biali mogli zagwarantować stabilność i postęp. Popierali zatem imigrację z Europy ${ }^{60}$. Zgodnie $\mathrm{z}$ mitem równości rasowej ${ }^{61}$ kubańscy niewolnicy zostali zatem uwolnieni przez swoich panów w czasie wojny dziesięcioletniej, co wyeliminowało obowiązek rekompensaty za wcześniejsze złe traktowanie. Skoro równość rasową osiągnięto już w szeregach armii kubańskiej walczącej z Hiszpanią, to funkcjonowała ona w republice kubańskiej. Mit ten zaprzeczał istnieniu dyskryminacji rasowej, zaś istniejące nierówności tłumaczono gorszymi umiejętnościami czarnych.

54 Na temat różnic w postrzeganiu rasy w USA i w Ameryce Łacińskiej zob. C. E. Rodríguez, Changing Race. Latinos, the Census, and the History of Ethnicity in the United States, New York 2000, s. 106-125.

55 A. de la Fuente, $A$ Nation for All..., s. 23.

56 Szerzej na temat José Martíego zob. np. T. Fernández Robaina, Cuba. Personalidades en el debate racial, La Habana 2007, s. 78-84, Etnología (Havana, Cuba).

57 A. de la Fuente, $A$ Nation for All..., s. 25.

58 A. Ferrer, Insurgent Cuba..., s. 7-8.

59 Cyt. za: A. Ferrer, Rethinking Race and Nation in Cuba, [w:] Cuba, the Elusive Nation. Interpretations of National Identity, red. D.J. Fernández, M. Betancourt Cámara, Gainesville 2000, s. 66.

60 A. de la Fuente, $A$ Nation for All..., s. 25-26, 34.

61 A. Helg, Our Rightful Share..., s. 45, 105-106; R.D. Moore, Nationalizing Blackness. Afrocubanismo and Artistic Revolution in Havana, 1920-1940, Pittsburgh 1997, s. 28. 
Afrokubańczycy, którzy nadal podnosili kwestię dyskryminacji rasowej, byli wręcz stygmatyzowani jako rasiści - skoro bowiem dyskryminacja nie istniała, protesty te skierowane były przeciw białym i godziły w narodowe braterstwo ${ }^{62}$.

Z kolei zgodnie z ludową interpretacją ideologii nacjonalistycznej (popular interpretation) głoszoną przez afrokubańskich intelektualistów nadal należało podejmować działania na polu społecznym i politycznym na rzecz równości ras. Sprzeciwiali się oni także przemilczaniu tej kwestii, gdyż jak podkreśla de la Fuente, postrzegali oni równość ras jako cel, nie zaś osiągnięcie. Jednak nie wszyscy afrokubańscy intelektualiści z klasy średniej godzili się z tą radykalną wizją, uważając, że Afrokubańczycy powinni zapracować na swoje miejsce w społeczeństwie poprzez edukację i samodoskonalenie ${ }^{63}$.

\section{WYBIELANIE. MIGRACJA Z EUROPY ${ }^{64}$}

W okresie poprzedzającym uniezależnienie się Kuby od Hiszpanii rozwijająca się wyspa przyciągnęła wielu Hiszpanów ${ }^{65}$. W latach 1847-1874 do pracy sprowadzono też znaczącą liczbę około 125 tys. robotników kontraktowych z Chin. W efekcie w roku 1877 osoby o chińskich korzeniach stanowity $3 \%$ populacji wyspy ${ }^{66}$.

Po 1898 r. działania zarówno w sferze polityki imigracyjnej, jak i polityki wewnętrznej dobitnie wyrażały stanowisko władz w kwestiach rasowych.

Na przełomie XIX i XX w. rozpowszechnione były idee darwinizmu społecznego, eugenika oraz rasizm naukowy, w Stanach Zjednoczonych obowiązywały dodatkowo tzw. prawa Jima Crowa. W Ameryce Łacińskiej, jak zauważa Howard J. Wiarda, $w X I X w$. i na poczatku XX w. kryteria rasowe staty się nawet ważniejsze niż $w$ okresie kolonialnym, zaś w toku swej historii Ameryka Eacińska przyjęta i wchtonęta większość teorii rasowych Europy i Ameryki Pótnocnej ${ }^{67}$. Elity podjęły się zatem trudnego zadania przekształcenia społeczeństw z „zacofanych” w „cywilizowane”. A sposobem na jego realizację miało być wybielenie społeczeństw przez wspieranie imigracji z Europy.

Polityka imigracyjna Kuby faworyzowała przyjazd całych rodzin, nie zaś pojedynczych robotników kontraktowych, wracających zwykle do Hiszpanii po zakończeniu zbiorów. Chodziło bowiem nie tyle o wybielenie społeczeństwa poprzez związki międzyrasowe, co o obecność białych rodzin i ich wkład w zmianę demografii wyspy ${ }^{68}$. Podejście

62 A. Helg, Our Rightful Share..., s. 16. Szerzej zob. tamże, s. 105-106.

A. de la Fuente, $A$ Nation for All..., s. 25-26, 34.

Zob. tamże, s. 45-53, 100-105.

J.C. Moya, Spanish Emigration to Cuba and Argentina, [w:] Mass Migration to Modern Latin America, red. S.L. Baily, E.J. Míguez, Wilmington 2003, s. 16-17, Jaguar Books on Latin America Series, 24.

66 N. Sánchez-Albornoz, Population of Latin America, 1850-1930, [w:] Europa, Asia y Africa en América Latina y el Caribe, red. B. Leander, Paris-Mexico 1989, s. 127; zob. też J. Guanche, Componentes étnicos..., s. 53-61.

67 H.J. Wiarda, The Soul of Latin America..., s. 199. Szerzej zob. tamże, s. 198-203; zob. też L. Martinez-Echazabal, Mestizaje..., s. 24-30.

68 A. Helg, Our Rightful Share..., s. 7. 
to pokazuje, że przez wielu niewolnicy i wyzwoleńcy nie byli traktowani jako pełnoprawna część społeczności kubańskiej. Jak zauważa Fernández Robaina, Ci pierwsi byli zwyktymi narzędziami pracy, a ci drudzy istotami marginalizowanymi we wszystkich przestrzeniach publicznych, pracy i wypoczynku zajetych przez Hiszpanów i biatych Kubańczyków ${ }^{69}$.

Szacuje się, że w latach 1902-1931 odnotowano przyjazd niemal 800 tys. Hiszpanów ${ }^{70}$. Ogólnie jednak efekt wysiłków mających na celu kolonizację Europejczykami nie był do końca zadowalający. W przeciwieństwie do zakładanej migracji całych rodzin przybyszami byli głównie samotni mężczyźni, którzy przyjeżdżali tylko na czas zbiorów trzciny cukrowej ${ }^{71}$. Duża grupa zasiliła także miasta. Poza Hiszpanami na Kubę w tym okresie przybyli też inni Europejczycy, a wśród nich Anglicy (ok. 20 tys.) i Francuzi (ok. 6 tys.). W latach 20. XX w. napłynęła też fala z Europy Środkowej i Południowej (Włosi - ok. 6,5 tys., Polacy - ok. 8,5 tys., Rosjanie - ok. 4 tys.), co w dużym stopniu było wynikiem wprowadzenia przez Stany Zjednoczone systemu kwotowego w 1921 i 1924 r. Wielu migrantów dostrzegło wówczas w Kubie atrakcyjny kraj tranzytowy, z którego docelowo mieli udać się do Stanów Zjednoczonych ${ }^{72}$. Ponieważ ważnym czynnikiem kształtującym politykę imigracyjną wyspy było zapotrzebowanie na pracowników na plantacjach trzciny cukrowej, pod naciskiem producentów cukru w 1913 r. zezwolono także na przyjazd robotników z Antyli (Jamajczyków oraz Haitańczyków) - w sumie około 310 tys. Nowe prawo imigracyjne z 1917 r. umożliwiło z kolei ponownie przyjazd Chińczyków (wcześniej zabroniony najpierw na mocy amerykańskich przepisów, jakim podlegała okupowana przez USA wyspa, a potem regulacji przyjętych już w niepodległej Kubie) ${ }^{73}$.

Hiszpanie byli traktowani preferencyjnie na rynku pracy, w rezultacie czego zdominowali niektóre stanowiska (w handlu, przemyśle, jako tymczasowi pracownicy w rolnictwie przy trzcinie cukrowej $)^{74}$. W 1929 r. redaktorzy afrokubańskiej kolumny Ideales de una raza gazety „Diario de la Marina” narzekali, że czarni na Kubie są uwięzieni między obcokrajowcami w miastach i obcokrajowcami na wsi ${ }^{75}$. Wzrastające z czasem niezadowolenie z obecności imigrantów na Kubie i ich konkurencyjności na rynku pracy spowodowało powstanie kilku projektów restrykcyjnych ustaw, wśród których znajdowały się prawo kwotowe i projekt zamrożenia imigracji ${ }^{76}$. Ostatecznie Kuba prowadziła politykę otwartych drzwi do rewolucji w 1933 r. Wówczas to rząd podjął zdecydowane

69 T. Fernández Robaina, Identidad afrocubana, cultura y nacionalidad, Santiago de Cuba 2009, s. 38.

70 M. Bejarano, La inmigración a Cuba y la politica migratoria de los EE.UU (1902-1933), „Estudios Interdisciplinarios de América Latina y el Caribe” 1993, Vol. 4, nr 2, [online] http://eial.tau.ac.il/index. $\mathrm{php/eial/article/view/1242/1270,} 20$ XII 2015.

71 A. de la Fuente, A Nation for All..., s. 101.

72 M. Bejarano, La inmigración a Cuba...

73 Zob. też A. Kaganiec-Kamieńska, Polityka imigracyjna wybranych państw Ameryki Eacińskiej na przetomie XIX i XX w., „Studia Migracyjne. Przegląd Polonijny” 2012, z. 4.

74 Zob. np. A. de la Fuente, A Nation for All..., s. 116 (Tabela 3.3. „Index of Participation, Economic Sectors and Occupations, by Race and Nativity, 1899-1943”). Szerzej zob. tamże, s. 115-128.

75 Cyt. za: A. de la Fuente, A Nation for All..., s. 115.

76 Zob. A. Helg, Our Rightful Share..., s. 101-102. 
decyzje, nakazując repatriację bezrobotnych imigrantów oraz tych, którzy nie mieli stałego źródła utrzymania. Na mocy prawa Ley de Naturalización de Trabajo określono nowe warunki zatrudniania imigrantów, wprowadzając wymóg, by odtąd co najmniej $50 \%$ pracowników stanowiły osoby urodzone na $\mathrm{Kubie}^{77}$.

Ostatecznie imigracja doprowadziła w pewnym stopniu do „wybielenia” społeczeństwa kubańskiego. O ile bowiem w 1899 r. biali stanowili 70\% populacji, o tyle w 1943 r. - 74,5\%. Jednak po zakończeniu polityki proimigracyjnej i w wyniku ogólnej poprawy warunków życia prowadzącej do spadku wskaźnika śmiertelności wśród czarnych i Mulatów grupa biała zaczęła stopniowo się zmniejszać, stanowiąc $66 \%$ populacji w $1981 \mathrm{r}^{78}$

\section{POLITYKA WEWNĘTRZNA}

\section{Przemoc i represje państwowe}

Konstytucja z 1901 r. nadała czarnoskórym mężczyznom prawa wyborcze, co było wówczas ewenementem w krajach o dużej populacji o afrykańskich korzeniach ${ }^{79}$. Tym samym czarnoskórzy wyborcy stali się istotni zarówno dla Partii Liberalnej, jak i Konserwatywnej. Problematyczne w „równym pod względem rasowym” społeczeństwie było uformowanie się w 1908 r. Partido Independiente de Color (PIC), zrzeszającej osoby o korzeniach afrykańskich i mającej zapewnić Afrokubańczykom większy dostęp do urzędów publicznych. Jedyny wówczas afrokubański senator Martín Morúa Delgado - wyznający pogląd, że Afrokubańczycy powinni zintegrować się ze społeczeństwem głównego nurtu, a nie tworzyć zorganizowanych grup - wniósł w 1909 r. do Kongresu poprawkę, na mocy której zabronione miało być tworzenie partii politycznej na bazie rasy ${ }^{80}$. Po przyjęciu poprawki na początku 1910 r., partia PIC spotkała się z represjami. Jak podaje Andrews, do jesieni 1910 r. aresztowano około jej 200 członków ${ }^{81}$. Niezadowolenie z delegalizacji partii doprowadziło w 1912 r. w regionie Oriente do zbrojnego protestu, określanego jako „wojna rasowa”, której ofiarą padło około 5-6 tys. czarnych i Mulatów ${ }^{82}$ - zarówno członków PIC i ich zwolenników, jak i osób niezwiązanych z partią. „Wojna rasowa” rzuciła cień na mit równości rasowej, tym bardziej że przeciwko swoim dawnym towarzyszom broni stanęło wielu białych weteranów walk o niepodległość ${ }^{83}$. Po 1912 r. ponownie nasiliły się napięcia na tle

Dane liczbowe zob. Tabela 2, [w:] M. Bejarano, La inmigración a Cuba...; G.R. Andrews, Afro-Latin America..., s. 154.

G.R. Andrews, Afro-Latin America..., s. 154-156 (Tabele 5.1 i 5.2).

80 A. Helg, Our Rightful Share..., s. 40-41, 165.

81 G.R. Andrews, Afro-Latin America..., s. 129.

82 A. Helg, Our Rightful Share..., s. 225. Szerzej na temat masakry zob. tamże, s. 194-226.

83 Tamże, s. 237. 
rasowym, a nawet podjęto próby wprowadzenia segregacji w przestrzeni publicznej (np. w parkach) $)^{84}$.

Do akceptacji ze strony białego społeczeństwa aktów przemocy wymierzonej w czarnych przyczyniało się stereotypowe ukazywanie czarnoskórych w ówczesnej prasie, która podsycała niepokój i traktowała ich jako zagrożenie. Czarnoskórych mężczyzn przedstawiano jako brujos zajmujących się czarną magią i porywających białe dziewczęta w celu wykorzystania ich do swoich obrzędów lub jako gwałcicieli białych kobiet. Z kolei czarne kobiety i mulatas nierzadko ukazywano jako uwodzicielskie i rozwiązłe. W tym kontekście Stany Zjednoczone pokazywane były jako obrońca białej Kuby (jak na grafice przedstawiającej Kubę jako białą kobietę z Wujkiem Samem). Na innych ilustracjach za piłkę białemu kubańskiemu żołnierzowi i amerykańskiemu marine służyły głowy Evaristo Estenoza i Pedro Ivonneta, przywódców protestu w Oriente. Tak jak wcześniej Kuba i USA walczyły wspólnie przeciwko Hiszpanii, tak Stany Zjednoczone pomagały teraz Kubie bronić „białą cywilizacje” przed „czarnym barbarzyństwem" 85 .

\section{Czarnoskóry znaczy zacofany. Kultura afrokubańska}

W wydarzenia polityczne lat 1900-1925 wpisują się także represje wobec kultury afrokubańskiej. Przyświecająca białej kubańskiej elicie idea „ucywilizowania” społeczeństwa dotyczyła bowiem również sfery kulturowej.

Mimo że kultura afrokubańska podlegała ograniczeniom już wcześniej, to jednak największe represje zaczęły na nią spadać od lat 80. XIX w. Jak zauważył Rine Leal, kiedy czarny [stał się] "wolny", potencjalnie równy biatemu, wówczas konieczne stato się znalezienie nowych metod dyskryminacji, które ukazatyby jego dzikosic ${ }^{86}$. Przykładowo, pod koniec lat 80 . XIX w. niektórych miastach zabroniono uprawiania afrokubańskiego gatunku muzycznego danzón, chociaż wykazywał jedynie niewielkie wpływy afrykańskie. Danzón zaczął jednak stopniowo cieszyć się nieco większą akceptacją, a po $1898 \mathrm{r}$. (i wkroczeniu na Kubę gatunków amerykańskich, takich jak foxtrot) wzrosło jego znaczenie jako muzyki wyrosłej na własnym, kubańskim gruncie. Nie podnoszono jednak kwestii jego afrykańskich korzeni ${ }^{87}$.

Również w niepodległej Kubie ograniczano korzystanie z afrykańskich instrumentów perkusyjnych oraz zwracano uwagę na "nieobyczajny” taniec. „Zgorszone” afrykańskimi rytmami, paradami i tańcami elity ingerowały również w obchody karnawału - znacząco go „cywilizując”. Determinacja rządzących była ogromna, o czym świadczą wydane zakazy. W 1913 r. burmistrz Hawany zezwolił na udział w karnawale karnawałowych grup muzyków afrokubańskich zwanych comparsas, pod warunkiem że powstrzymają się od lubieżnych tańców i nie będą używać afrykańskich

\footnotetext{
A. de la Fuente, A Nation for All..., s. 78-80.

A. Helg, Our Rightful Share..., s. 17-18, 227-248.

Cyt. za: R.D. Moore, Nationalizing Blackness..., s. 30.

Tamże, s. 18-30.
} 
instrumentów ${ }^{88}$. Ponieważ instrumenty te próbowano zastąpić bębnami wojskowymi, wkrótce w zasadzie całkowicie uniemożliwiono udział czarnych comparsas. Sam prezydent Gerardo Machado (1925-1933) w 1925 r. wydał zakaz używania na ulicach w całym kraju bębnów lub podobnych instrumentów afrykańskich oraz kontynuowania tańców stanowiacych obrazę moralności ${ }^{89}$.

Niepokój kubańskiej elity budziły też kultywujące tradycyjne zwyczaje organizacje etniczne cabildos afrocubanos. W latach 80. XIX w. zakazano im praktykowania rytuałów, tańców, używania bębnów i parad w święta religijne, tworzenia nowych cabildos, nakazano im też przekształcić się w stowarzyszenia pomocowe lub kluby na wzór hiszpański ${ }^{90}$. Próbowano zniszczyć ich związki z afrokubańskimi religiami, takimi jak abakuá, santería, palo monte. Co więcej, podczas wojny w latach 1895-1898 około 500 członków lóż abakuá deportowano do więzień w afrykańskich posiadłościach hiszpańskich ${ }^{11}$.

\section{REAKCJA}

Czarni i mieszani rasowo Kubańczycy odpowiadali elitom politycznym promującym białą wizję lo cubano na kilku polach.

\section{Mobilizacja - przed i po 1898 r.}

Występujący przeciwko Hiszpanii gente de color połączyli walkę narodowowyzwoleńczą z własną walką z niewolnictwem i rasizmem, pokładając w niej wielkie nadzieje i widząc ją jako szansę na poprawę ich miejsca w społeczeństwie.

Postrzeganie siebie jako członków grupy de color ewoluowało z negatywnego w stronę pozytywnego, czemu towarzyszyło poczucie dumy, odwaga, determinacja i wzrost aktywności. Byli równocześnie czarnymi i Kubańczykami, a więc byli równi białym. Właśnie to przekonanie stało się podstawą ich działań ${ }^{92}$. Czarny niewolnik mógł się stać obywatelem, a społeczeństwo oparte na niewolnictwie mogło przekształcić się w wolny naród. Powstańcy walczący w wojnie dziesięcioletniej oraz w wojnie o niepodległość z 1895 r. świadomie przyjęli też nazwę mambí. Uważa się, że termin ten powstał na Dominikanie jako (pejoratywne) określenie osób, które nie chciały się poddać rządom Hiszpanów w latach 1861-1865, a więc w czasie, gdy Hiszpanie nadal podtrzymywali niewolnictwo na Kubie i w Portoryko. Dla samych rewolucjonistów kubańskich termin ten nabrał pozytywnego znaczenia i w drugiej połowie XIX w. oznaczał rebelianta ${ }^{93}$. Tadeusz Łepkowski zwrócił uwagę, że armia

Szerzej na temat comparsas w karnawale kubańskim zob. tamże, s. 62-86.

89 Tamże, s. 71-72, 229-232.

90 R.L. López Valdés, Pardos y Morenos esclavos..., s. 238-244.

91 G.R. Andrews, Afro-Latin America..., s. 122.

92 A. Helg, Our Rightful Share..., s. 13-14.

93 P.A. Roberts, The Roots of Caribbean Identity..., s. 336-339, 449. Co ciekawe, w latach 80. XIX w. 
wyzwoleńcza mambises odegrała ważną rolę w wykształcaniu tożsamości narodowej: W jej szeregach zlewaty się w jednolita catość koleżeństwa, solidarności i braterstwa broni różne kondycje spoteczne i rozmaite kolory skóry. Byta to armia ludowa, byta to armia kubańska ${ }^{94}$.

Ogłoszona przez rząd rebeliancki podczas wojny dziesięcioletniej „równość ras” oraz zniesienie praw kastowych ${ }^{95}$ dodatkowo zachęcały czarnoskórych do przyłączenia się do walki. Czarnoskórzy niewolnicy stali się Cubanos negros oraz ciudadanos de color. W 1886 r. zniesiono niewolnictwo, zaś wielu szeregowych żołnierzy za swoje męstwo i bohaterstwo zdobyło stopnie oficerskie poruczników, kapitanów, a nawet generałów. Jak podkreśla Robaina, mieli oni petna świadomość znaczenia swego udziatu w przysztej $w^{2 j n i e^{96}}$. Również biali zrozumieli, że czarny Kubańczyk musi być brany pod uwagę w planach narodowowyzwoleńczych.

Ada Ferrer zwraca uwagę, że podczas wojny w latach 1895-1898 rasa była „przemilczana". Skoro przeciwnicy niepodlegtości mówili o rasie - niewolnictwie, sktadzie rasowym wyspy, wojnie rasowej - to aby ich pokonać, dziatacze na rzecz niepodlegtości musieli odrzeć rase z jej ideologicznego znaczenia. Musieli przemilczé́ kwestie rasy ${ }^{97}$. Temat rasy powstańców przemilczano zatem np. w dokumentacji powstańczej. Jak podaje autorka, lista około 40 tys. powstańców, którzy przeżyli wojnę, zawiera ich nazwiska i inne dane osobowe (w tym imiona rodziców, miejsce urodzenia, umiejętność czytania i pisania, zadania i obowiązki w oddziale powstańczym etc.), nie podaje jednak ich rasy. Również w dokumentacji szpitali powstańczych próżno szukać podobnych danych. Czarnoskórzy powstańcy walczyli jako patrioci.

Niestety, udział czarnych i Mulatów w walce niepodległościowej doprowadził do podziałów wśród uczestników powstania antyhiszpańskiego. W połowie lat 70. XIX w. niektórzy biali wycofali swoje poparcie dla toczonych działań. Podobnie w czasie La Guerra Chiquita wielu białych uznało motywy kierujące czarnymi powstańcami za rasistowskie, a samą wojnę za wstęp do wojny rasowej ${ }^{98}$. Rzeczywistość w oddziałach odzwierciedlała też poniekąd stosunki rasowe panujące na Kubie, bowiem wśród żołnierzy dominowali czarnoskórzy, zaś większość oficerów stanowili biali. Nadal też deprecjonowano zasługi czarnych ${ }^{99}$. Ferrer przytacza anegdotę o przyjęciu zorganizowanym w Gibara (prowincja Oriente) po zwycięstwie w 1898 r. Podczas gdy kubańscy kolorowi oficerowie zaprosili wszystkich towarzyszy broni, by wspólnie świętować

dowodzono indiańskich korzeni tego terminu, co można uznać za próbę jego nobilitacji i włączenia do „białego” świata. Jednak zdaniem wybitnego antropologa kubańskiego Fernando Ortiza ma on korzenie afrykańskie.

94 T. Łepkowski, Archipelagu dzieje nietatwe..., s. 252-253.

95 G.R. Andrews, Afro-Latin America..., s. 113.

96 T. Fernández Robaina, Identidad afrocubana..., s. 40-41.

97 A. Ferrer, Rethinking Race..., s. 64.

98 Tamże.

99 Zob. np. wspomnienia czarnoskórego żołnierza Ricardo Batrella Oviedy: A. Ferrer, Insurgent Cuba..., s. 160-162; taż, Rethinking Race..., s. 68-72. 
kubańsko-amerykańskie zwycięstwo, to następnego dnia zorganizowano dwa kolejne przyjęcia - jedno dla białych, a drugie dla Mulatów i czarnych ${ }^{100}$.

Jak podaje Ferrer, osoby o afrykańskich korzeniach stanowily w walkach niepodległościowych około $60 \%$ uczestników, a pod koniec okresu walk mieli stanowić około $40 \%$ oficerów ${ }^{101}$, w tym takich, którzy zasłużyli na miano bohaterów narodowych, jak np. główny dowodzący sił rebelianckich Antonio Maceo.

\section{Poziom organizacyjny}

\section{Organizacje spoteczne i polityczne}

Poza polem bitwy inną sferą działalności Afrocubanos były organizacje i stowarzyszenia. Pierwszą organizacją utworzoną przez czarnych Kubańczyków po zniesieniu niewolnictwa było Directorio Central de las Sociedades de Raza de Color założone w $1887 \mathrm{r}$. przez Juana Gualberto Gómeza. Grupowało ono różne organizacje i stowarzyszenia czarnej klasy średniej, a jego celem była walka przeciwko segregacji rasowej oraz o równe prawa ${ }^{102}$. Do 1893 r. Directorio Central udało się m.in. doprowadzić do zniesienia ograniczeń dotyczących segregacji w edukacji publicznej i usługach. Prawa te jednak bywały ignorowane przez np. instytucje takie jak hotele czy restauracje $\mathrm{e}^{103}$.

Wspomniane już Partido Independiente de Color (PIC) ${ }^{104}$, mające zapewnić Afrokubańczykom większy dostęp do urzędów publicznych, zrzeszało zarówno byłych sympatyków Partii Liberalnej (jak Evaristo Estenoz), jak i Partii Konserwatywnej (jak Pedro Ivonnet). Powstanie PIC nie spotkało się jednak z poparciem ze strony wielu afrokubańskich intelektualistów. Przykładowo Juan Gualberto Gomez opowiadał się za tym, by Afrokubańczycy pracowali w obrębie istniejących partii politycznych, zaś Martín Morúa Delgado uważał, że jakakolwiek próba budowy organizacji politycznej czarnych stanie się impulsem do powstania podobnej inicjatywy ze strony białych, co będzie nieuchronnie generować konflikty ${ }^{105}$. PIC zdołała wziąć udział jedynie w wyborach w 1908 r., nie odniosła jednak sukcesu ${ }^{106}$. Brutalne stłumienie wspomnianej już rebelii w Oriente (1912) pokazało ciemnoskórym, że de facto w żadnym wypadku nie można mówić o braterstwie w społeczeństwie kubańskim, a wolność $i$ równość byty wartościami elastycznymi, ksztattowanymi zgodnie z wola biatych ${ }^{107}$. Jednak sama rola Afrokubańczyków jako potencjalnych wyborców Partii Liberalnej i Konserwatywnej nadal

\footnotetext{
100 Taż, Insurgent Cuba..., s. 196.

101 Tamże, s. 3.

102 A. Helg, Our Rightful Share..., s. 35-43.

103 G.R. Andrews, Afro-Latin America..., s. 114

104 A. Helg, Our Rightful Share..., s. 4. Szerzej na temat powstania partii i jej programu zob. tamże, s. $142-$ -159; T. Fernández Robaina, Identidad a frocubana..., s. 103-126.

105 A. de la Fuente, A Nation for All..., s. 69-73.

106 G.R. Andrews, Afro-Latin America..., s. 129.

107 A. Helg, Our Rightful Share..., s. 6.
} 
pozostała ważna. Po 1912 r. Afrokubańczycy nie zdołali już stworzyć organizacji, która mogłaby odegrać rolę polityczną. Od lat 20. zaczęli natomiast angażować się w działalność związków zawodowych i organizacji lewicowych funkcjonujących ponad podziałami rasowymi ${ }^{108}$.

\section{Obrona kultury i tradycji afrokubańskiej. Cabildos}

Afrokubańskie organizacje etniczne zwane cabildos powstawały na Kubie, już począwszy od XVI w. ${ }^{109}$ Kolonizatorzy postrzegali je wówczas jako potencjalne źródło rebelii, ale ponieważ spełniały one dla ich członków funkcje rozrywkowe, równocześnie widziano w nich swoisty zawór bezpieczeństwa zapobiegający buntom. Jak podaje López Valdés, około połowy XVIII w. na Kubie funkcjonowało 21 cabildos de nación, a ich liczba wrosła wraz z napływem niewolników do około $50 \mathrm{w} 1812$ r. ${ }^{110}$ Te stowarzyszenia samopomocowe stanowily pewnego rodzaju alternatywny sposób życia. Cabildos de nación zrzeszające niewolników przywiezionych z Afryki były miejscem, gdzie pielęgnowano język, kulturę, muzykę, tańce i wierzenia afrykańskie (jakkolwiek ulegające modyfikacjom pod wpływem kultury hiszpańskiej i religii katolickiej). Z kolei cabildos de criollos zrzeszające osoby urodzone na wyspie - nadal te tradycje podtrzymywały. Skutkowało to powstaniem nowych religii afrokubańskich, takich jak santería ${ }^{111}$.

Co istotne, jak pokazuje López Valdés, cabildos nie ogrywały ważnej roli w działaniach rebelianckich, jakkolwiek niektórzy ich członkowie brali w nich czynny udział. Nie miały też bezpośredniego wpływu na przenikanie elementów afrykańskich do kubańskiej kultury narodowej - ważniejsze znaczenie w tym względzie miały bowiem takie czynniki, jak liczebność i miejsce koncentracji poszczególnych grup afrykańskich oraz kultywowanie ich tradycji przez kreolskich potomków ${ }^{112}$.

Wśród białej części społeczeństwa afrokubańska kultura i religia wzbudzały jednak strach i przekonanie, że są powiązane z magią, czarami, rytualnym jedzeniem ludzkiego mięsa (antropofagia) i przestępczością. Dodatkowo atmosferę wrogości podsyciły morderstwa w 1904 r. dwóch dziewczynek, które w przekonaniu opinii publicznej (i sądów) zostały zabite przez czarnoskórych (10-latka miała zginąć, prawdopodobnie broniąc się przed gwałtem, a 20-miesięczna dziewczynka miała paść ofiarą afrykańskich rytuałów). Niektóre gazety, jak podaje Helg, niemal zachęcały do linczów na brujos. W tej sytuacji oskarżenia wobec białych gazet o podżeganie do przemocy wysunęły: elitarne czarne stowarzyszenie Club Atenas, które wydało manifest poparty przez organizacje de color w całym kraju, oraz czarna gazeta „La Antorcha” wydawana przez członków młodej klasy średniej w Hawanie, która opublikowała specjalny suplement na ten temat. Na lincze

108 Tamże, s. 246. Szerzej zob. G.R. Andrews, Afro-Latin America..., s. 146-150.

109 Szerzej na temat cabildos de nación, cabildos criollos oraz różnic między nimi a cofardías zob. R.L. López Valdés, Pardos y Morenos esclavos..., s. 95-286, 355-356.

110 Tamże, s. 192-193, 266.

111 Tamże, passim.

112 Tamże, s. 17, 224-225, 269-271. 
zareagowali również afrokubańscy weterani wojenni. Jak zauważa Helg, na kilka tygodni w lipcu 1919 r. udało się odnowić jedność w grupie afrokubańskiej ${ }^{113}$.

\section{Podziały wewnątrz społeczności afrokubańskiej}

Zaznaczające się po uzyskaniu niepodległości w grupie afrokubańskiej podziały ze względu na klasę i kulturę utrudniały pokonanie mitu równości rasowej ${ }^{114}$. Chociaż większość nadal pozostawała na dole drabiny społecznej, to czarna klasa średnia często sama wyznawała ten mit, co tworzyło wyraźną przepaść między nimi a resztą grupy. Szczególnie młodzi intelektualiści i przedstawiciele wolnych zawodów, chociaż nadal byli dumni z wkładu czarnych w wojnę o niepodległość, świadomie chcieli się zasymilować ze społeczeństwem kubańskim. Krytykowali nagonkę na brujos, ale krytykowali także „prymitywne” formy kultury, w tym comparsas. Nie starali się zrozumieć wierzeń ludowych. W pewnym sensie poparli wojnę wytoczoną przeciwko kulturze afrykańskiej kojarzonej z klasą pracującą. Czarna klasa średnia chciała reprezentować kulturę „cywilizacji” - europejską. Już w 1893 r. afrokubańska gazeta „La Igualdad” w relacji z karnawału skrytykowała comparsas, które przywdziały stroje niewolnicze, ponieważ przypominały one czasy hańby niewolnictwa ${ }^{115}$. Z kolei na spotkaniach afrokubańskich klubów towarzyskich grano danzón, często zabraniano jednak używania bębnów lub wykonywania rumby i sonu, a jeszcze w latach 50 . XX w. także mambo ${ }^{116}$. Czarna elita „na swój sposób” zatem negocjowała miejsce Afrokubańczyków w społeczeństwie.

\section{„RASA KUBAŃSKA”. „KUBA METYSKA”. TRANSKULTURACJA}

\section{„Nacjonalizacja czerni”}

Okres przedefiniowania tożsamości narodowych i kultury rozpoczął się w regionie wraz ze zmianami gospodarczymi i politycznymi oraz odejściem od „wybielania” społeczeństw. Ideologia "demokracji rasowej” 117 zaznaczyła się także na Kubie, a jej pisanym manifestem stała się wspomniana praca Fernando Ortiza Contrapunteo cubano del tabaco y el azucar z $1940 \mathrm{r}$.

Zmiany w postrzeganiu korzeni afrykańskich i ich wkładu w kulturę kubańską dokonywały się jednak już wcześniej. W latach 1930 i 1931 poeta Nicolas Guillén wydał

113 A. Helg, Our Rightful Share..., s. 17, 109-112, 238-243.

114 Tu i dalej: tamże, s. 243-245.

115 G.R. Andrews, Afro-Latin America..., s. 125.

116 R.D. Moore, Nationalizing Blackness..., s. 39-40.

117 M.in. José Vasconcelos (Raza cósmica, 1925); Gilberto Freyre (Casa-grande e senzala [Panowie i niewolnicy], 1933; Sobrados e mucambos, 1936); Carlos Siso (La formación del pueblo venezolano, 1941). G.R. Andrews, Afro-Latin America..., s. 166. 
swoje „mulackie wiersze”, w których rysuje się obraz Kuby jako Cuba mestiza ${ }^{118}$. Guillén wraz z Ortizem przyczynili się do stworzenia wizji Kuby jako narodu o jednej, wspólnej wszystkim jej mieszkańcom kulturze narodowej ${ }^{119}$.

Jeszcze wcześniej, bo w latach 20. XX w., narodził się międzyrasowy ruch afrocubanismo (1920-1940) 120, którego członkowie poszukiwali istoty cubanidad (czy lo cubano) w korzeniach afrykańskich. Członkami tego ruchu byli m.in. pisarze i artyści sztuk wizualnych przekonani o konieczności przedefiniowania tożsamości kubańskiej. Był wśród nich np. czarnoskóry rzeźbiarz Teodoro Ramos Blanco, który w 1929 r. zdobył pierwszą nagrodę w krajowym konkursie na pomnik ku czci Mariany Grajales (matki generała Antonio Maceo) oraz złoty medal na wystawie iberoamerykańskiej Exposición Iberoamericana w Sewilli za rzeźbę Niewolnik (El Esclavo $)^{121}$. Do ruchu należeli także Nicolás Guillén, jak również biali autorzy i artyści, tacy jak Emilio Ballagás, José Tallet, Alejandro García Caturla oraz Ernesto Lecuona. Kładąc nacisk na afrykańskie korzenie, afrocubanismo ponownie uznało jednak ważną rolę rasy.

Za prezydentury Machado (1925-1933) relacje między Afrokubańczykami a rządem poprawiły się, a sam prezydent na wiele sposobów uznał ich wkład w niepodległość kraju i kulturę. Zwiększyła się także ich liczba w administracji rządowej ${ }^{122}$. Mimo zmian w oficjalnym dyskursie na temat rasy i miejsca osób o afrykańskich korzeniach w konstruowaniu tożsamości i kultury narodowej rasa pozostała bardzo ważnym czynnikiem zarówno w okresie I republiki (1902-1933), jak i II republiki (1933-1958).

W rzeczywistości lat 20. i 30. XX w. elementy kulturowe o wyraźnie afrykańskich korzeniach (taniec, muzyka) ${ }^{123}$ - do niedawna ukrywane i zabraniane - stały się najbardziej „autentyczna” ekspresją narodowej wyjątkowości. Tym samym zachodzące zjawiska można, za Robinem Moorem, określić jako nacjonalizacja czerni ${ }^{124}$. W 1925 r. Machado, jak podaje Andrews, wyraził swoje poparcie dla sonu i zatwierdził organizację pierwszego festiwalu tej muzyki, a nawet zaprosił jedną z grup, by zagrała na jego przyjęciu urodzinowym. Mimo obiekcji ze strony elity i klasy średniej son, podobnie jak rumba, stał się nowym symbolem kultury popularnej, w dużej mierze dzięki radiu i przemysłowi fonograficznemu (a rumba dodatkowo dzięki popularności, jaką zdobyła

118 Motivos de son (1930), Sóngoro cosongo. Poemas mulatos (1931). Szerzej zob. np. N. Guillén, Man-Making Words. Selected Poems of Nicolás Guillén, przeł., red. R. Márquez, D.A. McMurray, Amherst 2003. L. Martinez-Echazabal, Mestizaje..., s. 38.

120 Szerzej zob. R.D. Moore, Nationalizing Blackness..., s. 122-127, 132-146. Mniej więcej od lat 40. $\mathrm{XX}$ w. spadło zainteresowanie twórców z klasy średniej wątkami afrykańskimi. Nadal jednak utrzymało się w kulturze popularnej. Tamże, s. 221-223.

121 Na temat Teodora Ramos Blanco zob. np. A.G. Alonso, Ramos Blanco. Señales para el autorreconociemiento, „Revolución y Cultura” 1982, nr 123, s. 10-15.

122 Zob. A. de la Fuente, A Nation for All..., s. 91-95.

${ }^{123} \mathrm{Na}$ temat rozwoju afrokubańskich gatunków muzycznych i form tanecznych oraz form synkretycznych (afrohiszpańskich, jak np. contradanza i danzón) na Kubie zob. R.D. Moore, Nationalizing Blackness..

124 Zob. tamże, zwl. s. 114-146. 
w Europie i USA w latach 20. i 30. ${ }^{125}$. Na fali przemian politycznych i ekonomicznych oraz popularyzacji niektórych gatunków kubańskich w Stanach Zjednoczonych i Europie od 1937 r. comparsas ponownie mogły uczestniczyć w obchodach karnawału, z tym że musiały się najpierw zarejestrować, paradowały pod okiem policji i prezentowały pokazy, które, jak ujął to Andrews, bytyby bardziej atrakcyjne zarówno dla Kubańczyków, jak i turystów z US $A^{126}$. Karnawał w 1937 r. rzeczywiście przyciągnął wielu turystów, a miasto Hawana ufundowało nawet nagrody pieniężne dla najlepszej grupy ${ }^{127}$.

Również religie włączające elementy afrykańskie - uznawane przecież za niebezpieczne - doczekały się zainteresowania. Próbę ukazania religii i tradycji afrykańskich jako wartościowych, a nie gorszych względem kubańskich podjął m.in. jeden z największych czarnych myślicieli tego okresu Gustavo E. Urrutia ${ }^{128}$. Tematem owego „folkloru” zajmowali się również Fernando Ortiz (w książce Los Cabildos Afrocubanos, 1921) i Rómulo Lachatañeré (w artykule El sistema religioso de los lucumis y otras infuencias africanas en $\mathrm{Cuba})^{129}$.

Sami Kubańczycy o korzeniach afrykańskich nie przyjęli używanego przez Urrutię terminu afrocubanos (Afrokubańczyk) ${ }^{130}$. Określali siebie raczej jako cubano negro („czarny Kubańczyk”, kładąc tym samym nacisk na przynależność do narodu kubańskiego), a nie jako negro cubano („czarny z Kuby”, co wskazywałoby przede wszystkim na przynależność do grupy rasowej). Termin afrocubano nie stał się sposobem samookreślenia i identyfikacji, lecz elementem dyskursu intelektualnego. Jak zauważa Fernández Robaina, pojawiał się on w artykułach czy esejach, choć i tak nie wszyscy się nim posługiwali, czego przykładem jest sam Nicolás Guillén ${ }^{131}$.

\section{Segregowana rzeczywistość}

Zerwanie z europeizacją i wybielaniem oraz uznanie i rehabilitacja rasy czarnej na $\mathrm{Ku}-$ bie były jednak w dużym stopniu gestem. W rzeczywistości bowiem, mimo retoryki oraz uznania ich praw w Konstytucji z 1940 r., czarnoskórzy i Mulaci nadal doświadczali dyskryminacji na rynku pracy ${ }^{132}$. W latach 20. i 30. XX w. parali się głównie pracą fizyczną (murarstwo, praca w dokach portowych) oraz rzemieślniczą (krawcy, szewcy, piekarze). Niewielu z nich wykonywało prace urzędnicze (w administracji publicznej) czy wolne zawody (np. prawnika). Segregacja zdarzała się w parkach i na plażach. Jak pisze Moore, jeszcze w latach 50. XX w. w niektórych hotelach w kraju odmawiano

125 G.R. Andrews, Afro-Latin America..., s. 166-167. Na temat sonu i rumby zob. R.D. Moore, Nationalizing Blackness..., s. 87-113, 166-190.

126 G.R. Andrews, Afro-Latin America..., s. 168.

127 R.D. Moore, Nationalizing Blackness..., s. 80-86.

128 Szerzej na temat myśli Urrutii zob. T. Fernández Robaina, Cuba. Personalidades..., s. 43-47.

129 Tenże, Identidad afrocubana..., s. 43.

$130 \mathrm{Na}$ temat terminu afrocubano i jego użycia przez Ortiza i Urrutię zob. tamże, s. 73-84.

131 Tamże, s. 43-44.

132 Szerzej zob. T. Fernández Robaina, Cuba. Personalidades..., s. 127-133. 
pokoju osobom ciemnoskórym, chociaż w późniejszym okresie mogli być w nich zatrudniani jako muzycy, co nie zdarzało się niemal nigdy w latach 20. i 30. Podobnie wiele najlepszych klubów i kabaretów nie wpuszczało (i nie zatrudniało) czarnoskórych, w najlepszych teatrach nie zatrudniano ciemnoskórych muzyków, a ciemnoskóra publiczność siedziała zazwyczaj na galeriach (ze względów ekonomicznych). To samo dotyczyło klubów towarzyskich, jak np. Havana Yacht Club, który miał podobno odmówić członkostwa samemu prezydentowi Batiście ze względu na jako afrykańskie korzenie $^{133}$. Również w miejscach rozrywki klasy pracującej wydzielano strefy dla czarnych i białych. Segregacja nie obowiązywała w zasadzie jedynie w małych kabaretach i klubach, lokalnych teatrach, burdelach czy „akademiach tańca” praktycznie funkcjonujących również jako centra prostytucji ${ }^{134}$.

Warto zauważyć, że ówczesna czarna elita zajmowała specyficzne położenie w społeczeństwie Kuby. Dystansując się wobec czarnej klasy niższej, czarna klasa średnia nie uzyskała jednak akceptacji ze strony białej klasy średniej, musiała więc tworzyć własne organizacje, stowarzyszenia i kluby (w tym tańca i drużyny sportowe) funkcjonujące równolegle do białych. Należały do nich choćby wspomniany już elitarny Club Atenas w Hawanie czy El Progreso w Santiago. Na styku niższej klasy średniej i wyższej klasy niższej powstawały też organizacje pomocowe, takie jak Centro de Cocheros w Hawanie ${ }^{135}$.

Należy jednak podkreślić, że niektórzy Afrokubańczycy skorzystali z możliwości, jakie oferowało im państwo. Powszechny system edukacji publicznej i możliwości edukacyjne pozwolity im na pewien awans społeczny i zawodowy (m.in. wolne zawody), niektóre szkoły prywatne przyjmowały jednak nadal tylko białych. O ile w 1899 r. na Kubie był, przykładowo, tylko jeden afrokubański prawnik, dziesięciu lekarzy i 102 nauczycieli, to 30 lat później było już 174 czarnoskórych prawników, 158 lekarzy i 1375 nauczycieli, a około $4 \%$ grupy czarnoskórych wykonywało zawody wymagające odpowiednich kwalifikacji. Niemniej jednak nadal byli niedoreprezentowani w tych zawodach i gorzej opłacani. Mimo że pod względem edukacji i „kultury” spełniali warunki klasy średniej, to, jak stwierdził de la Fuente, ich kolor skóry, pochodzenie spoteczne i sytuacja finansowa, jak również biaty rasizm, trzymat ich niebezpiecznie blisko świata ubóstwa i pracowników fizycznych, z którego chcieli uciec ${ }^{136}$.

\section{ZAKOŃCZENIE}

Zarysowane procesy obrazują istniejące napięcia między tożsamością rasową a narodową na Kubie przed 1959 r. Z jednej bowiem strony nie ulega wątpliwości, że społeczność o korzeniach afrykańskich miała zasadniczy wkład w proces formowania kubańskiego

133 R.D. Moore, Nationalizing Blackness..., s. 34-38; A. de la Fuente, A Nation for All..., s. 158-160.

134 R.D. Moore, Nationalizing Blackness..., s. 40, 98-99.

135 G.R. Andrews, Afro-Latin America..., s. 126.

136 Szerzej zob. A. de la Fuente, A Nation for All..., s. 138-150, 153. 
społeczeństwa, kultury i tożsamości, z drugiej zaś strony ich rzeczywista rola była przez całe dekady marginalizowana i umniejszana. Nie pozostawało to bez związku z szerszym kontekstem społeczno-politycznym w regionie, dominującymi ideologiami oraz rolą USA. Poza zagranicznymi wpływami Kuba borykała się z własnymi, silnie zakorzenionymi obawami i przekonaniami rasowymi, według których osoby o korzeniach afrykańskich powinny się znajdować w pozycji podporządkowanej.

W procesie formowania kubańskiej tożsamości i kultury zarówno odgórnie kierowane procesy i działania, jak i oddolna reakcja były pełne sprzeczności.

Biali, którzy skorzystali pod każdym względem z szerokiego zaangażowania czarnych w walkę o niepodległość, po 1898 r. wykorzystywali mit jedności rasowej, piętnując protesty i aktywizm czarnoskórych jako „rasistowskie”, „niepatriotyczne” i jako zagrożenie dla jedności narodowej. Obarczano też czarnych winą za ich gorszą pozycję, bowiem w społeczeństwie równym rasowo brak awansu społecznego mógł być spowodowany jedynie brakiem osiągnięć z ich strony. Równocześnie administracja usilnie starała się przyciągnąć „cywilizowanych” imigrantów. Nacisk na imigrację białych i ograniczanie liczby przybyszów z Karaibów pokazuje, jak bardzo biała skóra była wpisana w ówczesną wizję „kubańskości”. Konstytucja nadała czarnoskórym prawa, nie przeszkadzało to jednak nadal marginalizować ich w przestrzeni publicznej (hotele, teatry, parki czy kluby). „Nacjonalizacja” niektórych elementów kultur afrykańskich nie przeszkadzała zaś w tym, by afrokubańskie formy religijne nadal kojarzone były z zacofaniem i czarną magią. Istnieje zatem wyraźna sprzeczność między legislacją i zapewnieniami o równości a próbą wybielenia Kuby i stosowaną przez białych przemocą, zarówno fizyczną, jak i symboliczną, by użyć terminu Pierre’a Bourdieu. Stopniowa zmiana retoryki i „nacjonalizacja” afrokubańskich elementów w ograniczonym stopniu zdołały odmienić rzeczywistość, w której osoby o afrykańskich korzeniach nadal doświadczały dyskryminacji.

Z drugiej strony sama grupa afrykańska z biegiem czasu stanowić zaczęła społeczność coraz bardziej heterogeniczną. Po uzyskaniu niepodległości niektórzy wybijający się przedstawiciele grupy włączyli się do polityki głównego nurtu (jak Juan Gualberto Gómez czy Martín Morúa) i głosili pogląd, że jedynie indywidualny wysiłek i praca pomogą osiągną́ sukces ${ }^{137}$. Zderzyło się to z aktywnością Afrokubańczyków w organizacjach społecznych i politycznych upominających się o swoje prawa. $\mathrm{O}$ ile zatem niektórzy woleli rasę „przemilczeć”, inni pokazywali, że ma ona kluczowe znaczenie dla członków grupy. Również pod względem praktyk kulturowych Afrokubańczycy stanowili grupę zróżnicowaną - od niewolników i byłych niewolników przywiązanych do kultury afrykańskiej po wolnych Kreoli identyfikujących się z kulturą dominującą. Awans społeczny, możliwy zresztą tylko dla niektórych, prowadził do dalszych wewnętrznych podziałów. Czarna i mulacka klasa średnia i zasymilowana elita w dużym stopniu wyznawały mit równości rasowej i dystansowały się od utożsamianej z kulturą afrykańską niższej klasy pracującej - mimo że ich pełny udział w społeczeństwie białych nie był do końca możliwy.

137 Szerzej zob. np. A. Ferrer, Rethinking Race..., s. 60-76. 
Rebecca Scott, która w swoich badaniach skupiła się na osobie niewolnika w okresie walk o emancypację Kuby, pokazała, że czarnoskórzy nie byli biernymi obserwatorami upadku niewolnictwa [...], a raczej manewrowali i dokonywali wyborów $w$ odpowiedzi na możliwości dostępne w spoteczeństwie ${ }^{138}$. Podobnie można powiedzieć, że po $1898 \mathrm{r}$. Kubańczycy o korzeniach afrykańskich aktywnie negocjowali swoje miejsce w społeczeństwie, mimo że w dużym stopniu przyswoili i zinternalizowali idee głoszone przez rządzących, co widać na przykładzie ich dążenia do wybielania przez związki małżeńskie. $\mathrm{Z}$ jednej strony bowiem stanęli do bezpośredniej konfrontacji z rasizmem i dyskryminacją rasową (na polu walki lub w formie czarnego aktywizmu). Z drugiej strony, świadomi ograniczeń porządku kolonialnego, jak również „białej” interpretacji „Kuby bezrasowej”, wykorzystywali mimo wszystko stworzone przez system kanały awansu społecznego.

\section{Postscriptum}

Mimo ideologicznej zmiany z Kuby „białej” w Kubę „metyską”, od lat 80. XIX w. spisy powszechne nieprzerwanie włączają pytanie o rasę (a dokładniej - o „kolor”) ${ }^{139}$. Mara Loveman twierdzi, że statystyki rasowe służyły dokumentowaniu procesu wybielania i „cywilizowania” ${ }^{140}$. Wydaje się jednak, że może to także odzwierciedlać głęboko zakorzenioną świadomość różnic rasowych, które mimo zmiany dyskursu nadal postrzegane były jako ważne.

Po 1959 r. Kuba stała się miejscem swoistej inżynierii spotecznej ${ }^{141}$. Reformy mające na celu wspomożenie i rozwój najniższych klas społecznych pomogły osobom o korzeniach afrykańskich w awansie społecznym i zawodowym. Likwidacja prywatnych szkół, klubów towarzyskich, miejsc rekreacji (plaż) oraz system szkół z internatem, jak również desegregacja (np. parków czy klubów towarzyskich) zlikwidowała dotychczasowe bariery między grupami i umożliwiła socjalizację młodego pokolenia w duchu jedności i kultury socjalistycznej ${ }^{142}$. Castro jednoznacznie powiązał dyskryminację rasową z dawnym systemem, a nierówności rasowe z „przywilejami klasowymi”. Rozwiązanie problemów klasowych było jednocześnie rozwiązaniem problemu nierówności rasowej. Już w 1962 r. rząd twierdził, że Kuba wyeliminowała problem dyskryminacji rasowej ${ }^{143}$. Rasa zniknęła z oficjalnego dyskursu ${ }^{144}$. Przemilczane uprzedzenia jednak nie zniknęly. Jak wskazuje de la Fuente: Chociaż rzadowe programy edukacyjne i kultural-

138 A.P. Maingot, Race, Color, and Class..., s. 223-224. Szerzej zob. R.J. Scott, Slave Emancipation in Cuba. The Transition to Free Labor, 1860-1899, Pittsburgh 2009, [online] http://digital.library.pitt.edu/cgi$\mathrm{bin} / \mathrm{t} /$ text/text-idx? idno=31735055592343; view=toc; c=pittpress., 20 XII 2015.

139 Zob. M. Loveman, National Colors..., s. 241 (Tabela 6.3).

140 Tamże, s. 246.

141 Zob. A. de la Fuente, $A$ Nation for All..., s. 336-337.

142 Szerzej zob. tamże, s. 260-285.

143 Tamże, s. 279. Szerzej zob. np. T. Fernández Robaina, Identidad afrocubana..., s. 11-32.

144 T. Fernández Robaina, Identidad afrocubana..., s. 11-32; A. de la Fuente, A Nation for All..., s. 279 i n. 
ne byty jawnie antyrasistowskie, to oficjalne przemilczanie rasy pozwolito na przetrwanie i reprodukcje ideologii rasowych, które znalazty podatny grunt w przestrzeni prywatnej. Uprzedzenia zatem są przekazywane młodszym pokoleniom w zaciszu domowym (często wielopokoleniowym, ze względu na problemy mieszkaniowe $)^{145}$.

De la Fuente niezwykle trafnie stwierdził, że powiązanie dyskryminacji rasowej z postawą antyrewolucyjną spowodowało, że w obliczu problemów, z jakimi zmaga się reżim, zachowania dyskryminujące stają się bardziej akceptowane. Częściowe otwarcie gospodarki kubańskiej w latach 90. (np. legalizacja dolarów amerykańskich i umożliwienie różnych form prywatnej działalności) miało pewne konsekwencje dla poszczególnych grup rasowych ${ }^{146}$. Zaobserwowano także przypadki dyskryminacji. De la Fuente stawia także ważne pytanie o przyszłość relacji rasowych na wyspie, również w kontekście możliwego odzyskania wpływów przez diasporę kubańską z USA (w większości białej klasy wyższej i średniej $)^{147}$. Pytanie to będzie coraz bardziej zyskiwało na znaczeniu, biorąc pod uwagę aktualnie nawiązywane relacje między Kubą a Stanami Zjednoczonymi oraz możliwość podróżowania Kubańczyków z USA do kraju pochodzenia. Rasa ponownie zatem staje się ważnym elementem rzeczywistości kubańskiej i istotnym czynnikiem kształtującym relacje społeczne.

\section{BIBLIOGRAFIA}

Alonso A.G., Ramos Blanco. Señales para el autorreconociemiento, „Revolución y Cultura” 1982, nr 123.

Andrews G.R., Afro-Latin America, 1800-2000, Oxford-New York 2004.

Appelbaum N.P., Macpherson A.S., Rosemblatt K.A., Introduction. Racial Nations, [w:] Race and Nation in Modern Latin America, red. też, New York 2003.

Bejarano M., La inmigración a Cuba y la política migratoria de los EE.UU (1902-1933), „Estudios Interdisciplinarios de América Latina y el Caribe" 1993, Vol. 4, nr 2, [online] http:// eial.tau.ac.il/index.php/eial/article/view/1242/1270.

Bokszański Z., Tożsamości zbiorowe, Warszawa 2005.

Dembicz A. i in., Stownik terminów geograficznych Ameryki Łacińskiej, Warszawa 1979.

Dzieje Ameryki Łacińskiej, t. 1, red. T. Łepkowski, Warszawa 1977.

Dzieje Ameryki Łacińskiej, t. 3, red. R. Mroziewicz, R. Stemplowski, Warszawa 1979.

Fuente A. de la, A Nation for All. Race, Inequality, and Politics in Twentieth Century Cuba, Chapel Hill 2001, Envisioning Cuba Ser.

Fernández Robaina T., Cuba. Personalidades en el debate racial (Conferencias y Ensayos), La Habana 2007, Etnologia (Havana, Cuba).

145 A. de la Fuente, $A$ Nation for All..., s. 19, 322-323.

146 Np. dostęp do dolarów amerykańskich mają osoby posiadające rodzinę w USA (większość trafia zatem do białych Kubańczyków) oraz pracujące w sektorach powiązanych z obrotem dolara, jak np. turystyka (sektor, w którym czarni są niedoreprezentowani). Tamże, s. 318-319.

147 Tamże, s. 19, 317-329, 338. 
Fernández Robaina T., Identidad afrocubana, cultura y nacionalidad, Santiago de Cuba 2009. Ferrer A., Insurgent Cuba. Race, Nation, and Revolution, 1868-1898, Jamaica 1999.

Ferrer A., Rethinking Race and Nation in Cuba, [w:] Cuba, the Elusive Nation. Interpretations of National Identity, red. D.J. Fernández, M. Betancourt Cámara, Gainesville 2000.

Freyre G., Panowie i niewolnicy, Warszawa 1985, Rodowody Cywilizacji.

Gershenhorn J., Melville J. Herskovits and the Racial Politics of Knowledge, Lincoln-London 2004.

Guanche J., Identificación de los componentes étnicos en Cuba. Contribución a su studio en los siglos XX y XXI, „Revista del CESLA” 2005, nr 7.

Guanche J., Componentes étnicos de la nación cubana, Warszawa 2004, Dokumenty Robocze Uniwersytet Warszawski. Centrum Studiów Latynoamerykańskich, 40.

Guillén N., Man-Making Words. Selected Poems of Nicolás Guillén, przeł., red. R. Márquez, D.A. McMurray, Amherst 2003.

Helg A., Our Rightful Share. The Afro-Cuban Struggle for Equality, 1886-1912, Chapel HillLondon 1995.

Herskovits M.J., The Myth of the Negro Past, New York-London 1941, [online] https://archive. org/details/mythofthenegropa033515mbp.

Heuman G., The Social Structure of the Slave Societies in the Caribbean, [w:] General History of the Caribbean, t. 3, red. F.W. Knight, London-Basingstoke 1997.

Kaganiec-Kamieńska A., Polityka imigracyjna wybranych państw Ameryki Łacińskiej na przetomie XIX i XXw., „Studia Migracyjne. Przegląd Polonijny” 2012, z. 4.

Larrain J., Identity and Modernity in Latin America, Malden, Mass. 2000.

Lisocka-Jaegermann B., Czarne Afryki, [w:] Dzieje kultury latynoamerykańskiej, red. M.F. Gawrycki, Warszawa 2009.

López Valdés R.L., Pardos y Morenos esclavos y libres en Cuba y sus instituciones en el Caribe Hispánico, San Juan 2007, Biblioteca del Centro.

Loveman M., National Colors. Racial Classification and the State in Latin America, New York 2014

Łepkowski T., Archipelagu dzieje nietatwe. Obrazy z przesztości Antyli. XV-XX w., Warszawa 1964, Biblioteka Wiedzy Historycznej. Historia Powszechna.

Maingot A.P., Race, Color, and Class in the Caribbean, [w:] Americas. New Interpretative Essays, red. A. Stepan, New York 1992.

Martinez-Alier V., Marriage, Class and Colour in Nineteenth-Century Cuba. A Study of Racial Attitudes and Sexual Values in a Slave Society, Ann Arbor 1989.

Martinez-Echazabal L., Mestizaje and the Discourse of National/Cultural Identity in Latin America 1845-1959, „Latin American Perspectives” 1998, Vol. 25, nr 3.

Moore R.D., Nationalizing Blackness. Afrocubanismo and Artistic Revolution in Havana, 1920-1940, Pittsburgh 1997.

Moya J.C., Spanish Emigration to Cuba and Argentina, [w:] Mass Migration to Modern Latin America, red. S.L. Baily, E.J. Míguez, Wilmington 2003, Jaguar Books on Latin America Se

Ortiz F., Hampa afro-cubana. Los negros esclavos; estudio sociológico y de derecho público, Havana 1916, [online] https://archive.org/details/hampaafrocubanal00ortiuoft.

Ortiz F., Contrapunteo cubano del tabaco y el azucar, Caracas 1978. 
Posern-Zieliński A., Między indygenizmem a indianizmem. Andyjscy Indianie na drodze do etnorozwoju, Poznań 2005, Etnologia i Antropologia Kulturowa - Uniwersytet im. Adama Mickiewicza w Poznaniu, nr 22.

Race and Ethnicity in America. A Concise History, red. R.H. Bayor, New York 2003.

Roberts P.A., The Roots of Caribbean Identity. Language, Race and Ecology, Cambridge 2008.

Sánchez-Albornoz N., Population of Latin America, 1850-1930, [w:] Europa, Asia y Africa en América Latina y el Caribe, red. B. Leander, Paris-Mexico 1989.

Sánchez Alonso B., The Other Europeans. Immigration into Latin America and the International Labour Market (1870-1930), „Revista de Historia Económica” 2007, Vol. 3.

Scott R.J., Slave Emancipation in Cuba. The Transition to Free Labor, 1860-1899, Pittsburgh 2009, [online] http://digital.library.pitt.edu/cgi-bin/t/text/text-idx ?idno=31735055592343; view $=$ toc; $c=$ pittpress.

Vasconcelos J., Rasa kosmiczna, przeł. J. Wojcieszak, Warszawa 1993, Idee i Ludzie, 4.

Wade P., Race and Ethnicity in Latin America, New York 1997.

Wiarda H.J., The Soul of Latin America. The Cultural and Political Tradition, New Haven-London 2001.

Dr Anna KAGANIEC-KAMIEŃSKA - doktor nauk społecznych w zakresie socjologii. Adiunkt w Zakładzie Ameryki Łacińskiej Instytutu Amerykanistyki i Studiów Polonijnych na Uniwersytecie Jagiellońskim. Jej zainteresowania badawcze koncentrują się na tożsamości, relacji między językiem a tożsamością oraz na polityce językowej w Ameryce Łacińskiej. Zajmuje się także grupą latynoską w USA. 